\title{
sciendo
}

DOI 10.2478/sbe-2019-0050

SBE no. 14(3) 2019

\section{AMBIDEXTERITY - A NEW PARADIGM FOR ORGANIZATIONS FACING COMPLEXITY}

\author{
OGREAN CLAUDIA \\ Lucian Blaga University of Sibiu, Romania \\ HERCIU MIHAELA \\ Lucian Blaga University of Sibiu, Romania
}

\begin{abstract}
:
Complexity is rapidly and inexorably leading the global economy towards new configurations and new dynamics; within this (ever fluid and unstable) framework, the strategic dualities that govern organizations and shape their strategic choices are not only multiplying but also interacting and generating unprecedented challenges: new pairs of (apparent) paradoxes occur, sophisticated interdependencies take place amongst them, and therefore new approaches in search for strategic solutions are imperatively asked. Against this background, the main goal of the paper is to suggest a paradigm of organizational ambidexterity - which gradually integrates various angles and valences into partial solutions and eventually comes up with a complex construct incorporating different levels of organizational ambidexterity and multiple patterns of ambidextrous behavior - able to (dynamically) position organizations on the coordinates of the complex global economy, while providing them with the essential tools needed to achieve strategic competitiveness. Thus, by addressing a major organizational challenge (strategic competitiveness) through the lens of complexity (seen both as defining feature of nowadays and science that provides the instruments to deal with it) and advocating for the solution of ambidexterity, the paper will enrich the theory of strategic management and will offer businesses an alternative to their strategic approaches.
\end{abstract}

Key words: ambidextrous organization; competitiveness; complexity

\section{Strategic competitiveness and the emergence of organizational ambidexterity}

Competitiveness represents a moving target for any business - "a marathon to achieve and sustain excellence" (Zahra, 1999) - and a dynamic indicator of its performance - as "performance is reflected in the firm's ability to achieve strategic competitiveness and earn above-average returns" (Hitt, Ireland \& Hoskisson, 2017). Basically, competitiveness is built on and reflects a firm's competitive advantage, while strategic competitiveness, at its turn, is based on sustainable competitive advantage - 
which defines "a firm that is able to outperform its competitors or the industry average over a prolonged period of time" (Rothaermel, 2015). But, "because competitive advantages are not permanently sustainable, firms must exploit their current advantages while simultaneously using their resources and capabilities to form new advantages that can lead to future competitive success" (Hitt, Ireland \& Hoskisson, 2014); in other words, they must be able of "competing today while preparing for tomorrow" (Abell, 1999), based on two different agendas, addressing both the current realities and the future contingencies.

This is a very solid argument, which (by itself) should lead businesses (through their strategists) towards an ambidexterity based approach of strategy and strategic management; but this is far from being so (simple), although there are more than four decades since Duncan (1976) has introduced the (concept of) ambidextrous organization and Miles et al. (1978) have provided guidance on the operationalization of organizational ambidexterity (even if not called it as such). Still, a series of significant steps have been made on the way towards the ambidextrous organization, and different approaches of organizational ambidexterity have emerged ever since, bringing relevant contributions to the literature, while opening new areas of fruitful research - (a). based on the argument that "ambidexterity is a useful way of framing the challenges organizations face in managing two competing objectives at the same time" (Birkinshaw, \& Gupta, 2013); and (b). realizing that "organizational ambidexterity gradually becomes a necessary condition for all firms that are trying to achieve long-term viability and prosperity in a discontinuous environment" (Stefanović, Prokić, \& Milošević, 2014).

\section{Ambidexterity "in practice" - main validations and disagreements}

Since its entrance on the strategy "arena" a few decades ago, organizational ambidexterity has caught the attention of many scholars trying to identify, demonstrate, and depict the dynamics of its relationship with firm performance - and particularly: (a). the viability of ambidexterity as determinant of organizational success; and (b). the practicalities that define a successful ambidextrous organization. Basically, the most significant researches envisage the following:

$\checkmark$ On organizational ambidexterity: the antecedents, consequences, and mediating role of organizational ambidexterity (Gibson, \& Birkinshaw, 2004); building ambidexterity into an organization (Birkinshaw, \& Gibson, 2004); a multilevel understanding of organizational ambidexterity (Simsek, 2009); a typology for aligning organizational ambidexterity's conceptualizations, antecedents, and outcomes (Simsek et al., 2009); the evolution of organizational ambidexterity (O'Reilly, \& Tushman, 2013); clarifying the distinctive contribution of ambidexterity to the field of organization studies (Birkinshaw, \& Gupta, 2013); organizational ambidexterity through the lens of paradox theory (Papachroni, Heracleous, \& Paroutis, 2015); how to put organizational ambidexterity into practice (Röglinger, Schwindenhammer, \& Stelzl, 2018);

$\checkmark$ On the ambidextrous organization: designing dual structures for innovation (Duncan, 1976); managing evolutionary and revolutionary change (Tushman, \& O'Reilly, 1996); building an ambidextrous organization (Birkinshaw, \& Gibson, 2004); a model of integrative strategy making processes (Andersen, \& Nielsen, 2007); how to 
achieve the ambidextrous organization (Markides, \& Chu, 2008); structuring ambidextrous organizations (Devins, \& Kähr, 2010); managing an ambidextrous organization (Sinha, 2016); ambidextrous organization and agility in big data era (Rialti et al., 2018);

$\checkmark$ On the relationship between ambidexterity and performance: balancing exploitation and exploration for sustained performance (Raisch, et al., 2009); microfoundations of performance: balancing efficiency and flexibility in dynamic environments (Eisenhardt, Furr, \& Bingham, 2010); exploring the relationships among ambidexterity, vacillation, and organizational performance (Boumgarden, Nickerson, \& Zenger, 2012); a meta-analysis of organizational ambidexterity and performance (Junni et al., 2013); the relationship between high-performance work systems and organizational ambidexterity (Patel, Messersmith, \& Lepak, 2013); organizational ambidexterity, market orientation, and firm performance (Wei, Zhao, \& Zhang, 2014); ambidexterity for corporate social performance (Hahn et al., 2016); ambidexterity, performance and environmental dynamism (Tamayo-Torres, Roehrich, \& Lewis, 2017).

More specifically, the literature validates the mediating role of ambidexterity on (the different facets and overall) organizational performance; thus: Kortmann et al. (2014) investigated the mediating role of ambidextrous operational capabilities in "linking strategic flexibility and operational efficiency"; Dutta (2013) examined "ambidexterity as a mediating variable in the relationship between dynamism in the environment, organizational context and strategic renewal"; Jurksiene, \& Pundziene (2016) analyzed the mediating role of organizational ambidexterity on "the relationship between dynamic capabilities and firm competitive advantage"; Lin, \& Ho (2016) explored the mediating role of organizational ambidexterity in the relationship between "institutional pressures and environmental performance in the global automotive industry". Overall, O'Reilly and Tushman (2013) concluded (in an extensive review of the state of the research) that "in spite of using different measures of ambidexterity, a range of outcome variables, different levels of analysis, and samples from differing industries, the results linking ambidexterity to performance are robust" (O'Reilly, \& Tushman, 2013), while Junni et al. (2013) founded (based on "a meta-analysis of prior studies on organizational ambidexterity and performance") that "positive and significant organizational ambidexterity - performance relationships are to a large extent moderated by contextual factors and methodological choices" (Junni et al., 2013).

Although quite impressive, most of the literature in the field of organizational ambidexterity deals with the exploration - exploitation dilemma of strategic choice - which is viewed as fundamental in performance seeking (especially if considering the financial bottom line). But, besides the (many) challenges this innovation dilemma (Bhoovaraghavan, Vasudevan, \& Chandran, 1996; Sharma, 1999; Cooper, 2011) (already) raises for companies and their strategists, a series of other pairs of strategic organizational dualities/opposites that govern the search for strategic competitiveness need to be simultaneously considered and (successfully) managed - through (a form of) organizational ambidexterity: deliberate strategy - emergent strategy (Mintzberg, \& Waters, 1985), standardization - customization (Swaminathan, 2001), profitability sustainability (Hawkins, 2006), efficiency - effectiveness (Simsek, 2009), or competition cooperation (Yami et al., 2010). Basically, "the simultaneous presence of opposites (i.e. 
paradoxes) is part of the everyday practice of management and not just an exception that can be willed away" (Clegg, da Cunha, \& e Cunha, 2002), while "at the heart of every set of strategic issues, a fundamental tension between apparent opposites can be identified" (De Wit, \& Meyer, 2010).

Therefore, there is an increasing literature on strategic organizational paradoxes, trying to solve them through ambidexterity (amongst other approaches); but again, most of the literature is focused just on the exploration - exploitation one, and too little attention is paid to other paradoxes / dualities and to their conjugated / integrated approach; thus, the literature's mainly focuses are: complex business models: managing strategic paradoxes simultaneously (Smith, Binns, \& Tushman, 2010); dynamic decision making: a model of senior leaders managing strategic paradoxes (Smith, 2014); how do firms manage strategic dualities? a process perspective (Birkinshaw, Crilly, Bouquet, \& Lee, 2016); ambidexterity: the combination of seemingly conflicting priorities (Alpkan, \& Aren, 2009); exploitation-exploration tensions and organizational ambidexterity: managing paradoxes of innovation (Andriopoulos, \& Lewis, 2009); toward a theory of paradox: a dynamic equilibrium model of organizing (Smith, \& Lewis, 2011); the role of dualities in arbitrating continuity and change in forms of organizing (Graetz, \& Smith, 2008); organizational paradoxes: dynamic shifting and integrative management (Bloodgood, \& Chae, 2010).

\section{The challenges of complexity - opportunities for the revival of organizational ambidexterity}

If referring to the broader context/environment of organizations (by including organizations within it), it is a truism to just state that there is a complex one; but complexity has become dominant and global, as:

$\checkmark$ "our economy, especially the global economy, is a complex system" (Homer-Dixon, 2011), which: (1). resulted from: growth in co-evolutionary diversity, structural deepening, the phenomenon of capturing software that encompasses all the good and bad sides of complexity; and (2). is characterized by: many components, high degree of connectivity between components, thermodynamically openness, information, matter, and energy flowing across the boundaries, nonlinear behaviors, and emergence (Homer-Dixon, 2011);

$\checkmark$ the global economy has become a "complex network, (where) everything is connected to everything else" (Barabasi, 2002): "companies, firms, corporations, financial institutions, governments, and all potential economic players are the nodes. Links quantify various interactions between these institutions (...). The weight of the links captures the value of the transaction, and the direction points from the provider to the receiver. The structure and evolution of this weighted and directed network determine the outcome of all macroeconomic processes" (Barabasi and Frangos, 2002).

The complexity of the external environment (encompassing myriads of different agents that interact in a far from predictable manner, enhancing the complexity) is continuously leading the global economy towards new configurations and new dynamics that challenge the current managerial approaches, forcing organizations to rethink their search for strategic competitiveness. Within this (ever fluid and unstable) framework: (a). 
organizations are defined by a plethora of dynamic ties and interdependencies that shape their strategic choices; (b). the strategic paradoxes / dualities facing organizations are not only multiplying, but also interacting and generating unprecedented challenges: new (apparent) paradoxes occur, sophisticated interdependencies take place among them, and therefore new approaches in search for strategic solutions are asked.

Both cause and consequence of the new global economy, organizations are becoming complex (adaptive) systems, exhibiting three characteristics: a number of heterogeneous agents, each making decisions about how to behave; interactions among the agents; and emergence (Sullivan, 2011). Consequently, the behavior of organizations as complex systems is defined by features such as: unpredictability; self-organization; inertia, chaos and evolutionary adaptation; setting up conditions for both incremental and radical change; establishing simple rules; accelerating evolution through flexibility; using adaptive tension to position at the edge of chaos (Grant, 2016).

As difficult it is to understand complexity from an organization perspective because "understanding complex systems is not to be found by recourse to the neoDarwinist synthesis, or generic algorithms, but by the application of holistic multi-level modelling methodologies and an understanding of socio-economic systems at different levels of aggregation" (Garnsey, \& McGlade, 2006) - it is more difficult to deal with it, as "no single map (model) is of itself a sufficient descriptor of a complex system (reality)" (Garnsey, \& McGlade, 2006); moreover, "most companies have not introduced or implemented yet a complexity management system/approach or they do not know, if the used complexity management strategy and methods, are efficient and adequate" (GorzeńMitka, \& Okręglicka, 2014). Nevertheless, although complexity has brought with it a series of unprecedented changes and challenges for companies, it has also come with valuable solutions for them, such as: improved forecasting methods, better risk mitigation, smart trade-off decisions (Sargut, \& McGrath, 2011).

Under these circumstances, the recent advancements in complexity sciences, and especially in the field of complexity economics open new opportunities for both research and practice, which need to be capitalized on, in order for firms to achieve strategic competitiveness. Thus, according to Arthur (2013), complexity economics "sees the economy (...) as one in motion, perpetually 'computing' itself - perpetually constructing itself anew. (...Within this paradigm), a solution is no longer necessarily a set of mathematical conditions but a pattern, a set of emergent phenomena, a set of changes that may induce further changes, a set of existing entities creating novel entities" (Arthur, 2013). On the other hand, Holt, Rosser Jr, \& Colander (2011) emphasize on the major methodological changes that accompany complexity: agent-based modeling, the use of "lab, field and natural experiments to determine what people actually do", the preeminence of empirical inductive reasoning over pure deductive reasoning, the replacement of set theory and calculus "by game theory, which seldom comes to a definite conclusion independent of the precise structure of the game" (Holt, Rosser Jr, \& Colander, 2011).

More specifically, particular contributions of complexity theory to strategy (and, subsequently, to the strategic management process's search for strategic competitiveness) have also been researched and identified. Thus, in their study "towards a complexity theory of strategy", Pina e Cunha and Vieira da Cunha (2006) have contributed "to the 
creation of a complexity theory of strategy by integrating a number of ideas that have previously been explored independently in the strategy literature, namely improvisation, minimal structures, simple rules, dynamic capabilities, bricolage, and organizational resilience" (Pina e Cunha, \& Vieira da Cunha, 2006); in order to "outline corporate strategy from the perspective of complexity theory", Eisenhardt and Piezunka (2011) have applied "the complexity perspective to the central strategic choices of corporate strategy, and compare the implications of complexity theory with those of traditional theories" (Eisenhardt, \& Piezunka, 2011).

Overall, Boulton and Allen (2015) have argued that a complexity theory perspective implies the following for strategy development: "first of all, it places central importance on adopting an integrative viewpoint; (...) second, it shows that creativity and adaptation are derived locally and through allowing diversity and interconnectivity to exist; (...) third, it emphasizes irreversibility and the limits of replicability; (... and) perhaps the most important contribution from complexity science centres around the concept of the tipping point. (...) The strategist must try and see the signs of instability and impending shifts and tread a fine line between riding the wave and shaping the fall" (Boulton, \& Allen, 2015).

\section{Form unsolved issues to the building blocks of the ambidextrous organization}

The analysis of the state-of-the-art in the field has revealed a series of limits / uncovered / underexplored research areas; addressing them will not only fill a gap in the literature, but will also contribute to the development of a new research agenda for (strategic) management, while helping organizations (and their strategists) to better understand the new challenges they are facing (due to increasing complexity) and to find the most suitable solutions (by capitalizing on the opportunities of ambidexterity) in their search for strategic competitiveness:

$\checkmark$ Definitional issues: according to O'Reilly and Tushman (2013), "the generic use of organizational ambidexterity is vague and simply refers to the ability of a firm to do two things simultaneously" (O'Reilly, \& Tushman, 2013); in the same line of though, Birkinshaw and Gupta (2013) argue that "the concept of organizational ambidexterity has been applied to a wide variety of phenomena. (...) Its growing appeal is a reflection of its versatility, but this versatility carries the risk of a lack of clarity in meaning and measurement" (Birkinshaw, \& Gupta, 2013). Even more elusive and/or elliptical is the concept of ambidextrous organization: while Rothaermel (2015) defines the ambidextrous organization in terms of "an organization able to balance and harness different activities in trade-off situations", most of the definitions in the literature are tributary to a specific ambidexterity capability analyzed - accentuating on the ideas of: "exploiting existing competencies (...) and exploring new opportunities" (Schreuders, \& Legesse, 2012); designing and operationalizing adequate structures to support ambidexterity (Boumgarden, Nickerson, \& Zenger, 2012); or "managing the present while preparing for the future" (Dover, \& Dierk, 2010); 
$\checkmark$ The lack of an integrative (across levels) view on organizational ambidexterity, leading to gaps between the different levels of approach and to the absence of a comprehensive view on what the ambidextrous organization really is or should become: if "shifting attention (...) to the micro - a single organizational process, project, or phase (new product development, for example) - would enable study of the solutions firms find to resolve specific tensions" (Nosella, Cantarello, \& Filippini, 2012) - on one hand, "future research may capture multiple levels of analysis and uncover how unit-level and firm-level or firm-level and interfirm-level characteristics contribute to achieving ambidexterity" (Jansen et al., 2009) - on the other hand; not least, "another promising domain for ambidexterity research is to move from the firm (or corporation) as unit of analysis to the firm's larger ecosystem" (O'Reilly, \& Tushman, 2013);

$\checkmark$ The need for dynamic approaches and longitudinal studies, which "may allow researchers to comprehend better how ambidexterity 'works in practice', including at the micro-level, to enhance our understanding of this subject, and its drivers and outcomes" (Turner, Swart, \& Maylor, 2013); these researches would be able to depict "how the organizational patterns emerge from the local agents and interactions, and the role of organizational boundaries and historical interactions on the pattern formation" (Akgün, Keskin, Byrne, \& Ilhan, 2014) - "in order to shed light on how ambidexterity coevolves, dynamically, with changes in the environment" (Nosella, Cantarello, \& Filippini, 2012);

$\checkmark$ The need for large scale (cross-sectional and/or longitudinal) approaches "examining the effects of a wide variety of paradoxes to determine how they interact and the extent to which organizations benefit from managing them integratively" (Bloodgood, \& Chae 2010), and, further on, to capitalize on "the potential (...of big data analytics...) to move ambidexterity research beyond its current focus on survey-based industry studies and selected case studies (...) towards more rigorous research designs where voluminous and diverse sources of data from multiple time-periods are analyzed to find patterns that our current theoretical models cannot" (Bøe-Lillegraven, 2014);

$\checkmark$ The complex relationships between organizational ambidexterity and performance: although previous studies have generally agreed on the strong correlations between (a specific kind of) organizational ambidexterity and performance, "the detailed operational mechanisms and linkages between ambidexterity and financial performance are not fully understood" (Turner, Swart, \& Maylor, 2013); secondly, research lacks "focus on multiple levels of organizational ambidexterity simultaneously to specify how linkages between organizational ambidexterity at different levels contribute to performance" (Junni et al., 2013) and, thirdly, "more research on potential mediators or moderators will also benefit practitioners and provide more guidance for their ambidextrous efforts" (Luo et al., 2017).

All the above advocate for the advancements made by both the theory and practice of organizational ambidexterity - towards the ambidextrous organization, while suggesting the huge untapped potential of this kind of approach. Against this background, the paper proposes in the following a new research agenda for strategic management - by introducing the ambidexterity-based strategic competitiveness paradigm, able to (dynamically) position the organization on the coordinates of the complex global economy while providing it with the essential tools needed to achieve strategic competitiveness. 
The hypotheses - to become the building blocks of this (theoretical) construct are the following:

$\checkmark$ as complexity (increasingly and endlessly) embraces the world into an unprecedented global network - wherein myriads of agents interact with each other "at the edge of chaos" - there is time for a paradigm shift as regards firms' search for strategic competitiveness;

$\checkmark$ in their (collective) capacity of being the main contributors to and receptors of complexity, firms are at the heart of the transformative processes changing both the defining features and the dynamics of the global environment - so the (particular) ways they will chose to address the challenges of complexity (in their search for competitiveness) will lead them towards being beneficiaries or victims of complexity;

$\checkmark$ the "either/or" traditional approach of strategic organizational paradoxes/dualities (coming from firms' interactions with a variety of both internal and external stakeholders) is no longer "the" solution - a refined (more complex) "both together" kind of approach is needed at firm level, one which relies on ambidexterity (as dynamic organizational capability), while being highly contextual (in time and space);

$\checkmark$ organizations, as complex adaptive systems, should be aware of the multiple strategic dualities they confront with in a complex global world, and be able to manage them simultaneously to their best interest - therefore needing specific / particular and dynamic models (consisting on multiple patterns and behaviors) of approaching ambidexterity;

$\checkmark$ for any firm searching for strategic competitiveness in a complex world ambidexterity should become a dynamic capability, endowed with the ability of transforming the liability of organizational paradoxes / dualities into a strategic asset - being thus able to efficiently and effectively balance the (continuous) process of co-evolution between an organization and its environment;

$\checkmark$ in order for the ambidexterity paradigm to become a viable solution for organizations searching for strategic competitiveness in a complex world, the entire transformative process at firm level should rely on a complexity approach - integrating: transdisciplinary viewpoints on organizations as complex adaptive systems, agent-based modelling, multi-purpose interacting patterns, network configurations, co-evolving behaviors, and so on - able to provide both the needed (instrumentation) means and the expected (validation) ends/outputs.

So, placing ambidexterity at the core of the search for strategic competitiveness is both a tremendous challenge and a boundless opportunity for organizations facing complexity.

\section{Designing, implementing and developing the new paradigm}

The paper (firstly) proposes a three stages evolution model towards the (truly) ambidextrous organization (Figure 1) - a framework for the gradual approach of organizational ambidexterity; thus, every firm could easily identify the "degree" of ambidexterity that defines it at a particular moment, in order to further on decide on the steps to follow. 
Figure 1. Stages of organizational ambidexterity

\begin{tabular}{|c|c|}
\hline Reactive behavior & Surviving \\
\hline Second degree ambidexterity \\
\hline Accomodating behavior & Fitting the environment \\
\hline Third degree ambidexterity - the truly ambidextrous organization \\
\hline Pro-active behavior & Co-evolution with the environment \\
\hline
\end{tabular}

Basically, each organization develops a form/degree of ambidexterity as long as it manages to survive (within the complex global environment) - by specifically addressing (based on the capitalization of its resources and capabilities) a series of (sometimes contradictory) internal and external demands coming from an increasing variety (and number) of stakeholders; but this kind of reactive behavior is able to generate only a "first degree ambidexterity", which maintains the organization "on the waterline", without being able to lead it towards competitiveness.

The "second degree ambidexterity", on the other hand, based on an accommodating behavior aiming to fit the organization with its environment (at a given moment in time), is able to generate (short-term) competitiveness by leveraging the potential of ambidexterity (as organizational capability) to reconcile the organization's internal demands with its external ones; this kind of ambidexterity can be reached through both trade-offs between conflicting (internal and external) demands and particular forms of ambidexterity (such as exploitation and exploration), but it is not enough in order to achieve strategic competitiveness.

This moving target can only be reached if embracing the "third degree ambidexterity", which defines the truly ambidextrous organization - one that consciously and permanently embodies ambidexterity (as complex and dynamic organizational capability) at its core, while exhibiting a (complex) pro-active behavior able to ensure the co-evolution between the organization and its environment; thus, the approach on organizational ambidexterity should be a holistic one (integrating different components and valences at multiple organizational levels, together with their dynamic ties and external determinants and consequences), while the ambidextrous organization will be defined by the optimal choice derived from multiple alternative patterns of behavior.

Within this framework, the premise that organizational ambidexterity is (to different degrees) found in the very "DNA of a living business" stands for the idea that, although it "means different things to different people" and "one size does not fit all", it represents a solid platform to build on - by practice and organizational learning and development. Thus, once organizations envision surviving and succeeding in a complex world through the lens of ambidexterity, they would be much more opened to discover and continuously develop 
their ambidextrous capabilities, while being able to define their own path towards the truly ambidextrous organization.

The three stages evolution model describes an analytical framework able to (secondly) support the search for ambidexterity-based sustainable competitiveness (Figure 2). Thus: (a). built on a complexity approach, organizations/firms (as complex adaptive systems) will be able to map the internal and external complexity-related challenges (together with their ties and interdependencies); (b). then, by capitalizing on organizational ambidexterity (as complex dynamic capability) firms will develop dynamic models to generate scenarios for strategic decision making; and (c). eventually strategic competitiveness will be reached through synergistic effects, able to ensure (in the same time) the co-evolution of the firm with its broader environment.

Figure 2. Reaching ambidexterity-based strategic competitiveness into a complex world

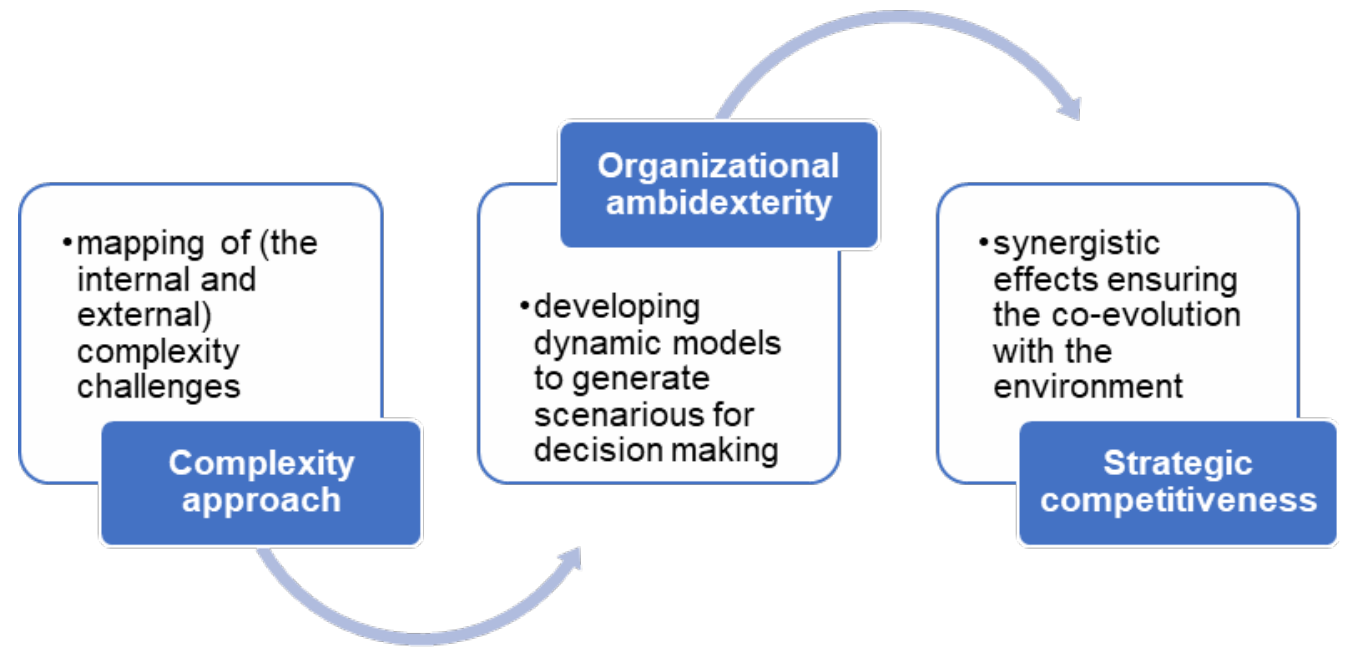

In order to implement / operationalize (and to further develop) this kind of approach, a firm will have to engage itself into quite an ambitious endeavor, which would involve the the following:

$\checkmark$ to categorize the impact of complexity (as defining feature of the internal and external organizational environment) on the organization (as complex adaptive system) which will comprise: (a). identifying and grouping the challenges of "external" complexity in terms of: new / different agents, emerging and continuously changing interconnections, evolving patterns of evolution; (b). finding "internal" complexity-related challenges - at different levels (corporate, business units, functional) and as concerns the organization's strategy, structure, culture, and processes; (c). bringing together the two kind of challenges through complex mapping;

$\checkmark$ to identify organizational paradoxes / dualities and their strategic challenges which will mean: (a). building a comprehensive and flexible (dynamic) framework of the multiple strategic dualities the organization is confronted with - both from within and from outside; (b). identifying possible dependencies and interdependencies within and among those dualities and assessing the importance of each variable for the strategic 
management process in different contexts; (c). designing a computational model able to generate various scenarios for decision making;

$\checkmark$ to get insights: (a). on the specific behaviors - patterns and routines - successful firms usually exhibit in order to deal with particular organizational paradoxes through ambidexterity; (b). on the characteristics that define an ambidextrous organization - in terms of strategies, business models, structures and cultures, main processes;

$\checkmark$ to configure the particular model for managing organizational paradoxes through ambidexterity - built on the specific triggering mechanisms, emerged patterns and processes involved, and considering the specific estimated outputs (evaluated in terms of organizational performance and especially strategic competitiveness);

$\checkmark$ to test the model for validation and future implementation, and to ensure its maintenance and development - through permanent updating (in terms of inputs to be considered, dynamics of the relationships among variables, and so on) and thorough evaluation of consequences and impacts.

Obviously, the complexity of this holistic, multi-level and trans-disciplinary endeavour makes the approach quite prone to high risks - (a). conceptually: many variables, lots of conditions and determinants, myriads of evolving interconnections, plethora of emerging behaviors, and so on; (b.) methodologically - collecting (big) data and managing (diverse and dynamic) information, map designing, identifying patterns, modeling behaviors, integrating different levels, and so on; and (c). managerially strategic myopia, core rigidities developed in time, resistance to change, losing focus, chaos, and so on.

\section{Conclusions}

The paper has suggests a paradigm of organizational ambidexterity - able to (dynamically) position organizations on the coordinates of the complex global economy, while providing them with the essential tools needed to achieve strategic competitiveness.

The proposed conceptual model is of importance (for both the theory of strategic management and the practice of business) because: (a). it addresses a major organizational challenge - strategic competitiveness, as measure or organizational performance - by advocating for a new, multi-level (from intra- to inter- firms, and beyond to global) and inter-disciplinary (social-, computational-, biological- sciences) approach; (b). it recommends the solution of ambidexterity - to be developed in line with the new realities and trends (that have transformed complexity into a dominant and global feature of nowadays), and through the lens (as well as the apparatus and the methodology) of complexity sciences; (c). it provides guidance for firms in strategizing and managing an ambidextrous organization while setting the backgrounds for a new organizational paradigm.

Overall, the paper have a series of theoretical implications - as it fills some gaps, while opening avenues for further research directions, on: (a). challenging the status quo of strategic management research and proposing a new research agenda - able to bring together two of the dominating paradigms of nowadays: complexity and ambidexterity; (b). the integrative - multi-level and inter-disciplinary approach of organizations - which helps 
them identifying and categorizing strategic organizational paradoxes, while facilitating dealing with them through ("multi-degree") ambidexterity; (c). redefining the search for strategic competitiveness against the background of (dominating) complexity and through complexity (sciences) lenses - by unleashing the potential of organizational ambidexterity (as dynamic capability) and fully capitalizing on it via the ambidextrous organization (as beneficiary of the successful bivalent strategic focus); (d). the complex, iterative process of modelling the ambidextrous organization - which will bring a plethora of new insights on (the motivators, the mechanisms, the features, the processes, the consequences, and so on, of) organizational ambidexterity - which will improve knowledge in the field, contributing to the development of a new research framework.

From a managerial perspective, the implications of the paper mainly refer to: (a). the argument for firms to envision themselves as complex adaptive systems - components of a global web of complex ties and interactions - which have to co-evolve with their environment in order to (successfully) survive; (b). the tools provided in order to support firms to properly position themselves on the new coordinates of the environment - through creating specific mechanisms and developing particular competencies to cope with complexity; (c). releasing firms from the burden of making "absolute choices" in terms of either/or when dealing with strategic paradoxes / dualities and opening new opportunities for them to explore "multiple choices" and gains - resulted from the valorization of their educated ability of being ambidextrous; (d). eventually developing of complex idiosyncratic agent-based models - able to optimally deal with the multiple paradoxes / dualities organizations are facing simultaneously - which will define the "fully" ambidextrous organization.

\section{References:}

Abell, D. F. (1999). Competing today while preparing for tomorrow. Sloan Management Review, 40(3), 73.

Akgün, A. E., Keskin, H., Byrne, J. C., \& Ilhan, Ö. Ö. (2014). Complex adaptive system mechanisms, adaptive management practices, and firm product innovativeness. $R \& D$ Management, 44(1), 18-41.

Alpkan, L., \& Aren, S. (2009, July). Ambidexterity: The combination of seemingly conflicting priorities. In Cape Town, 5th International Strategic Management Conference.

Andersen, T. J., \& Nielsen, B. B. (2007). The effective ambidextrous organization: a model of integrative strategy making processes. Working Paper, Center for Strategic Management and Globalization, Copenhagen Business School, Copenhagen.

Andriopoulos, C., \& Lewis, M. W. (2009). Exploitation-exploration tensions and organizational ambidexterity: Managing paradoxes of innovation. Organization Science, 20(4), 696-717.

Arthur, W. B. (2013). Complexity economics: a different framework for economic thought. In Complexity Economics, W.B. Arthur, Oxford Univ. Press, 2013

Barabasi, A. L. (2002). Linked: How everything is connected to everything else and what it means. Plume Editors.

Barabasi, A.L. and Frangos, J. (2002). Linked: The New Science of Networks. Perseus Publishing 
Bhoovaraghavan, S., Vasudevan, A., \& Chandran, R. (1996). Resolving the process vs. product innovation dilemma: A consumer choice theoretic approach. Management Science, 42(2), 232-246.

Birkinshaw, J., \& Gibson, C. (2004). Building ambidexterity into an organization. MIT Sloan Management Review, 45(4), 47.

Birkinshaw, J., \& Gibson, C. B. (2004). Building an ambidextrous organisation. Advanced Institute of Management Research Paper, (003).

Birkinshaw, J., \& Gupta, K. (2013). Clarifying the distinctive contribution of ambidexterity to the field of organization studies. The Academy of Management Perspectives, 27(4), 287-298.

Birkinshaw, J., Crilly, D., Bouquet, C., \& Lee, S. Y. (2016). How do firms manage strategic dualities? A process perspective. Academy of Management Discoveries, 2(1), 51-78.

Bloodgood, J. M., \& Chae, B. (2010). Organizational paradoxes: Dynamic shifting and integrative management. Management Decision, 48(1), 85-104.

Bøe-Lillegraven, T. (2014). Untangling the ambidexterity dilemma through big data analytics. Journal of Organization Design, 3(3), 27-37.

Boulton, J., \& Allen, P. (2015). Complexity Perspective. In Ambrosini, V., Jenkins, M., \& Mowbray, N. (Eds.). Advanced strategic management: A multi-perspective approach. Palgrave Macmillan.

Boumgarden, P., Nickerson, J., \& Zenger, T. R. (2012). Sailing into the wind: Exploring the relationships among ambidexterity, vacillation, and organizational performance. Strategic Management Journal, 33(6), 587-610.

Clegg, S. R., da Cunha, J. V., \& e Cunha, M. P. (2002). Management paradoxes: A relational view. Human relations, 55(5), 483-503.

Cooper, R. G. (2011). Perspective: The innovation dilemma: How to innovate when the market is mature. Journal of Product Innovation Management, 28(s1), 2-27.

De Wit, B., \& Meyer, R. (2010). Strategy synthesis: Resolving strategy paradoxes to create competitive advantage. Cengage Learning EMEA.

Devins, G., \& Kähr, C. N. (2010). Structuring ambidextrous organizations: Exploitation and exploration as a key for long-term success. In More than bricks in the wall: Organizational perspectives for sustainable success (pp. 60-67). Gabler.

Dover, P. A., \& Dierk, U. (2010). The ambidextrous organization: integrating managers, entrepreneurs and leaders. Journal of Business Strategy, 31(5), 49-58.

Duncan, R. B. (1976). The ambidextrous organization: Designing dual structures for innovation. The Management of Organization, 1, 167-188.

Dutta, S. K. (2013). Ambidexterity as a mediating variable in the relationship between dynamism in the environment, organizational context and strategic renewal. Jindal Journal of Business Research, 2(1), 27-41.

Eisenhardt, K. M., \& Piezunka, H. (2011). Complexity theory and corporate strategy. The SAGE handbook of complexity and management, 506-523.

Eisenhardt, K. M., Furr, N. R., \& Bingham, C. B. (2010). CROSSROADS - Microfoundations of performance: Balancing efficiency and flexibility in dynamic environments. Organization science, 21(6), 1263-1273.

Garnsey, E., \& McGlade, J. (Eds.). (2006). Complexity and co-evolution: continuity and change in socio-economic systems. Edward Elgar Publishing.

Gibson, C., \& Birkinshaw, J. (2004). Contextual determinants of organizational ambidexterity. Academy of Management Journal, 47(2), 209-226.

Gorzeń-Mitka, I., \& Okręglicka, M. (2014). Managing Complexity: A Discussion of Current Strategies and Approaches, Procedia Economics and Finance, Vol. 27, pp. 438-444 
Graetz, F., \& Smith, A. C. (2008). The role of dualities in arbitrating continuity and change in forms of organizing. International Journal of Management Reviews, 10(3), 265-280.

Grant, R. M. (2016). Contemporary strategy analysis: Text and cases edition. John Wiley \& Sons.

Hahn, T., Pinkse, J., Preuss, L., \& Figge, F. (2016). Ambidexterity for corporate social performance. Organization Studies, 37(2), 213-235.

Hawkins, D. (2006). Corporate social responsibility: balancing tomorrow's sustainability and today's profitability. Springer.

Hitt, M.A, Ireland, R. D., \& Hoskisson, R.E. (2014). Strategic Management. Competitiveness and Globalization. Stamford: Cengage Learning.

Holt, R. P., Rosser Jr, J. B., \& Colander, D. (2011). The complexity era in economics. Review of Political Economy, 23(3), 357-369.

Homer-Dixon, T. (2011) Complexity Science. Oxford Leadership Journal. January. Vol 2. Issue 1.

Jansen, J. J., Tempelaar, M. P., Van den Bosch, F. A., \& Volberda, H. W. (2009). Structural differentiation and ambidexterity: The mediating role of integration mechanisms. Organization Science, 20(4), 797-811.

Junni, P., Sarala, R. M., Taras, V., \& Tarba, S. Y. (2013). Organizational ambidexterity and performance: A meta-analysis. The Academy of Management Perspectives, 27(4), 299-312.

Jurksiene, L., \& Pundziene, A. (2016). The relationship between dynamic capabilities and firm competitive advantage: The mediating role of organizational ambidexterity. European Business Review, 28(4), 431-448.

Kortmann, S., Gelhard, C., Zimmermann, C., \& Piller, F. T. (2014). Linking strategic flexibility and operational efficiency: The mediating role of ambidextrous operational capabilities. Journal of Operations Management, 32(7-8), 475-490.

Lin, L. H., \& Ho, Y. L. (2016). Institutional pressures and environmental performance in the global automotive industry: the mediating role of organizational ambidexterity. Long Range Planning, 49(6), 764-775.

Luo, C., Zhang, D., Luo, B., \& Ge, J. (2017). Ambidextrous Strategy and Firm Performance: The Moderating Effects of Organizational Slack and Organizational Life Cycle. Business and Management Studies, 3(4), 1-11.

Markides, C., \& Chu, W. (2008). 19 Innovation through ambidexterity: how to achieve the ambidextrous organization. Handbook of Research on Strategy and Foresight, 324.

Miles, R. E., Snow, CC., Meyer, A. D., \& Coleman, H. J. (1978). Organizational strategy, structure, and process. Academy of Management Review, 3(3), 546-562.

Mintzberg, H., \& Waters, J. A. (1985). Of strategies, deliberate and emergent. Strategic management journal, 6(3), 257-272.

Nosella, A., Cantarello, S., \& Filippini, R. (2012). The intellectual structure of organizational ambidexterity: A bibliographic investigation into the state of the art. Strategic Organization, 10(4), 450-465.

O'Reilly, C. A., \& Tushman, M. L. (2013). Organizational ambidexterity: Past, present, and future. The Academy of Management Perspectives, 27(4), 324-338.

Papachroni, A., Heracleous, L., \& Paroutis, S. (2015). Organizational ambidexterity through the lens of paradox theory: Building a novel research agenda. The Journal of Applied Behavioral Science, 51(1), 71-93.

Patel, P. C., Messersmith, J. G., \& Lepak, D. P. (2013). Walking the tightrope: An assessment of the relationship between high-performance work systems and organizational ambidexterity. Academy of Management Journal, 56(5), 1420-1442.

Pina e Cunha, M., \& Vieira da Cunha, J. (2006). Towards a complexity theory of strategy. Management Decision, 44(7), 839-850. 
Raisch, S., Birkinshaw, J., Probst, G., \& Tushman, M. L. (2009). Organizational ambidexterity: Balancing exploitation and exploration for sustained performance. Organization science, 20(4), 685-695.

Rialti, R., Marzi, G., Silic, M., \& Ciappei, C. (2018). Ambidextrous organization and agility in big data era: the role of business process management systems. Business Process Management Journal, 24(5), 1091-1109.

Röglinger, M., Schwindenhammer, L., \& Stelzl, K. (2018). How to Put Organizational Ambidexterity into Practice - Towards a Maturity Model. In International Conference on Business Process Management (pp. 194-210). Springer, Cham.

Rothaermel, F. T. (2015). Strategic management. McGraw-Hill.

Sargut, G., \& McGrath, R. G. (2011). Learning to live with complexity. Harvard Business Review, 89(9), 68-76.

Schreuders, J., \& Legesse, A. (2012). Organizational ambidexterity: how small technology firms balance innovation and support. Technology Innovation Management Review, 2(2), 17.

Sharma, A. (1999). Central dilemmas of managing innovation in large firms. California Management Review, 41(3), 146-164.

Simsek, Z. (2009). Organizational ambidexterity: Towards a multilevel understanding. Journal of Management Studies, 46(4), 597-624.

Simsek, Z., Heavey, C., Veiga, J. F., \& Souder, D. (2009). A typology for aligning organizational ambidexterity's conceptualizations, antecedents, and outcomes. Journal of Management Studies, 46(5), 864-894.

Sinha, S. (2016). Managing an ambidextrous organization: balancing innovation and efficiency. Strategic Direction, 32(10), 35-37.

Smith, W. K. (2014). Dynamic decision making: A model of senior leaders managing strategic paradoxes. Academy of Management Journal, 57(6), 1592-1623.

Smith, W. K., \& Lewis, M. W. (2011). Toward a theory of paradox: A dynamic equilibrium model of organizing. Academy of Management Review, 36(2), 381-403.

Smith, W. K., Binns, A., \& Tushman, M. L. (2010). Complex business models: Managing strategic paradoxes simultaneously. Long range planning,43(2), 448-461.

Stefanović, I., Prokić, S., \& Milošević, D. (2014). Achieving Opposites Simultaneously: A Review of Organizational Ambidexterity. In Innovative Management and Firm Performance (pp. 139164). Palgrave Macmillan UK.

Sullivan, T. (2011). Embracing complexity. Harvard Business Review. September

Swaminathan, J. M. (2001). Enabling customization using standardized operations. California Management Review, 43(3), 125-135.

Tamayo-Torres, J., Roehrich, J. K., \& Lewis, M. A. (2017). Ambidexterity, performance and environmental dynamism. International Journal of Operations \& Production Management, 37(3), 282-299.

Turner, N., Swart, J., \& Maylor, H. (2013). Mechanisms for managing ambidexterity: A review and research agenda. International Journal of Management Reviews, 15(3), 317-332.

Tushman, M. L., \& O'Reilly, C. A. (1996). The ambidextrous organizations: Managing evolutionary and revolutionary change. California Management Review, 38(4), 8-30.

Wei, Z., Zhao, J., \& Zhang, C. (2014). Organizational ambidexterity, market orientation, and firm performance. Journal of Engineering and Technology Management, 33, 134-153.

Yami, S., Castaldo, S., Dagnino, B., \& Le Roy, F. (Eds.). (2010). Coopetition: winning strategies for the 21 st century. Edward Elgar Publishing.

Zahra, S. A. (1999). The changing rules of global competitiveness in the 21st century. The Academy of Management Executive, 13(1), 36-42 